\title{
Characterization of microorganisms present in a slaughterhouse and beef processing/chilling environment
}

\author{
Identificação de microrganismos presentes no ambiente de um matadouro-frigorífico de bovinos \\ Neida Terezinha Souza Macedo \& Sueli Teresinha Van Der Sand
}

\begin{abstract}
The ingestion of contaminated foods of animal origin has considerably increased the occurrence of food-borne diseases. Several bacterium species are deemed responsible for outbreaks of those diseases and the presence of such species in food processing plants depends on the proper hygiene routines there adopted. The aims of this study were: (i) to isolate and characterize the microorganisms present in a bovine slaughterhouse and processing/chilling environment, and (ii) to identify enterotoxigenic Escherihcia coli (ETEC) among isolates using the PCR amplification protocol. Out of the total 580 bacteria isolated and identified by biochemical assays, 168 were Staphylococcus aureus, 123 Escherichia coli, and 79 Corynebacterium vitarumem. The remaining belonged to the Bacillus spp. and Corynebacterium spp. genera, and to the Enterobacteriaceae family. The 123 bacteria identified as E. coli underwent a plasmid DNA extraction routine for the PCR assays. The results revealed $37 \mathrm{E}$. coli isolates to be positive for the ST gene, out of which 20 were correspondingly positive for the LT gene and 2 were only LT positive. The data evidenced the predominance of bacteria indicating faecal contamination and of bacteria found in bovine hides. The sampling sites of higher contamination were desks, in both the slaughterhouse and in processing/chilling plants inspected.
\end{abstract}

Key words: slaughterhouse, beef processing/chilling, bacteria, enterotoxigenic E. coli.

\section{RESUMO}

Episódios de doenças causadas pela ingestão de alimentos contaminados, principalmente os de origem animal, vêm aumentando consideravelmente. Várias espécies bacterianas têm sido responsáveis por estes surtos e a presença destes microrganismos em locais de industrialização e produção de alimentos está relacionada, principalmente, com a higienização inadequada realizada nestes ambientes. $\mathrm{O}$ trabalho teve como objetivo principal isolar e identificar os microrganismos presentes em um ambiente de matadouro-frigorífico de bovinos e através da amplificação por PCR identificar linhagens de Escherichia coli enterotoxigênicas entre os isolados. Um total de 580 bactérias foram isoladas e identificadas através das provas bioquímicas. Destas, 168 foram pertencentes a espécie Staphylococcus aureus, 123 a espécie Escherichia coli, 79 a espécie Corynebacterium vitarumem e as demais pertencentes aos gêneros Bacillus sp., Corynebacterium sp. e a família Enterobacteriaceae. As 123 bactérias identificadas como E. coli foram submetidas a extração de DNA plasmidial para os ensaios de PCR. Os resultados mostraram que 37 isolados de E. coli, foram positivos para o gene ST e destas, 20 também foram positivos para o gene LT e 2 foram somente positivos para o gene LT. Com os dados obtidos neste estudo foi possível observar a predominância de bactérias relacionadas com a contaminação fecal e bactérias originárias da pele dos bovinos. Os pontos com maiores índices de contaminação foram as mesas, tanto no matadouro como no frigorífico.

Descritores: matadouro, frigorífico, bactéria, Escherichia coli enterotoxigênica. 


\section{INTRODUCTION}

The occurrence of food poisoning and foodborne diseases has increased world-wide and in Brazil. Slaughterhouses and processing/chilling plants may become the place where microorganisms, oftentimes pathogenic, thrive and propagate depending on the hygienic and sanitary precautions taken. The relevance of bacteria lies in the fact that they are directly involved in the deterioration of meat, in infectious processes and food poisoning. Several infections in humans result from the ingestion of contaminated foods, specially of animal origin. The presence of bacteria in meat, in particular, is imputed to the faecal contamination of carcasses as of the rupture of intestines, and contact of meat, utensils and equipment with hides, hairs and hooves during evisceration [10]. According to some authors the meat contaminated inside the slaughterhouse, when processed, may carry microorganisms into other environments [9].

Escherichia coli naturally inhabits the intestine keeping a relationship of commensalism with the host. The enterotoxigenic E. coli (ETEC) is pathogenic to man and animals such as pig and cattle, and may produce types I and II heat-stable (ST) and types I and II heat-labile (LT) toxins. ETECs are nowadays held responsible for the vast majority of $E$. coli-associated diarrhea outbreaks world-wide [6], which are mostly due to the consumption of contaminated foods and water [7].

The aims of this study were: to isolate the bacterial population present inside the slaughterhouse prior to slaughter and inside the processing/chilling plant before beef processing, to characterize isolates via classic microbiologic assays, and to analyze the pathogenicity of E. coli isolates using PCR.

\section{MATERIALS AND METHODS}

\section{Sampling}

Samples were collected at one slaughterhouse/chilling plant, in the Greater Porto Alegre (RS, Brazil), in August, September and October 2001. The unit is regularly inspected by the local veterinary authorities. The sanitation of the entire place was always done after the end of the day shift and no sanitation was done in the beginning of the next day work. Sampling took place $12 \mathrm{~h}$ after the sanitizing, always prior the beginning of the day work, at one site in the slaughterhouse (boning desk), and at three sites at beef processing (ground beef machine, desk where skin-encased products are prepared, and the sealing machine where they are tied closed). Swabs were used to sample three $10-\mathrm{cm}^{2}$ patches on desks and areas in contact with the skin-encased products. After sampling, swabs were placed in tubes containing $9 \mathrm{~mL}$ peptone water $0.1 \%$.

Samples were also collected using plates containing culture media, placed at different points in the processing unit. The culture media used were BHI agar (Brain Heart Infusion) and MacConkey agar. Plates remained uncovered at the four corners of the room for approximately $30 \mathrm{~min}$.

After collections, samples were transported under refrigeration to the laboratory.

\section{Preparation of microbial isolates}

For the isolation of microorganisms, dilutions of between $10^{-1}$ and $10^{-3}$ were prepared in peptone water $0.1 \%$. Then, $1 \mathrm{~mL}$ of each dilution was seeded in duplicate using the pour plate method onto dishes containing BHI agar and EMB (Eosine Methyl Blue) agar and incubated at $37^{\circ} \mathrm{C}$ for $24-48 \mathrm{~h}$.

For the isolation of Yersinia, samples were preenriched in phosphate buffer saline (PBS, $\mathrm{pH}$ 7.6) and incubated at $4^{\circ} \mathrm{C}$ for 7,14 , and 21 days. The buffer provided 1-mL aliquots for each incubation period, which were seeded onto MacConkey agar using the pour plate technique, then incubated at $37^{\circ} \mathrm{C}$ for $24 \mathrm{~h}$ and at room temperature for extra $24 \mathrm{~h}$.

For the isolation of Salmonella, samples were pre-enriched in Müller-Kaufmann tetrathionate broth for $18 \mathrm{~h}$ at $43^{\circ} \mathrm{C}$, which after growth provided $1-\mathrm{mL}$ aliquots that were seeded onto $\mathrm{XLT}_{4}$ selective medium (Xylose-Lysine-Tergitol 4) and incubated at $37^{\circ} \mathrm{C}$ for 24-48 h.

\section{Isolate identification}

After the random selection of colonies isolated in each culture medium, bacterial isolates were grown in BHI broth and subsequently seeded onto BHI slants, which served the purpose of stocking isolates for subsequent bacterial isolation. The identification of isolates began with the Gram's method, followed by classic biochemical assays such as: oxidase, catalase, coagulase, TSI agar (Triple Sugar Iron), SIM medium (Sulphurate Indol Motility), Simmons citrate agar, phenylananine deaminase agar, urea broth, MR-VP broth (Methyl Red/Voges-Proskauer), 
OF medium (Oxidation/Fermentation), base medium for lysin decarboxylase, ornithine and arginine, carbohydrates and gelatine. Classification under genus and species after the biochemical assays followed $[11,12]$.

\section{Coliforms determination}

The number of total and faecal coliforms was established using the multiple tube fermentation technique [1].

\section{Extraction of the bacterial plasmid DNA}

The routine to extract the plasmid DNA of isolates and control strains was an adaptation of the alkali lysis technique [16]. The plasmid DNA was extracted from bacterial cultures grown in $20 \mathrm{~mL} \mathrm{BHI}$ broth for $16 \mathrm{~h}$. Each culture was centrifuged using a refrigerated centrifuge at 13,000 rpm for $1 \mathrm{~min}$. The pellet was washed in $\mathrm{NaCl} 1 \mathrm{M}$ and re-suspended in $200 \mathrm{~mL}$ solution I (50 mM glycose, $25 \mathrm{mM}$ Tris/HCl, $10 \mathrm{mM}$ EDTA) and $10 \mathrm{~mL}$ lysozyme $(10 \mathrm{mg} / \mathrm{mL})$. The mixture was kept at room temperature for 15 min. Subsequently, $400 \mathrm{~mL}$ of solution II was added $(0.2 \mathrm{~N} \mathrm{NaOH}, 1 \%$ SDS $)$. The mixture was incubated in ice for $5 \mathrm{~min}$. Next, $300 \mathrm{~mL}$ solution III was added $(60 \mathrm{~mL}$ potassium acetate $5 \mathrm{M}, 11.5 \mathrm{~mL}$ acetic acid, $28.5 \mathrm{~mL}$ distilled water) and again the mixture was kept in ice for $15 \mathrm{~min}$.

The DNA purification was done using extraction with phenol:chloroform. The DNA was precipitated in $0.3 \mathrm{M}$ sodium acetate and 2,5 volumes icecold absolute ethanol. The mixture was then incubated at $-20^{\circ} \mathrm{C}$ for $15 \mathrm{~min}$. Centrifugation at $13,000 \mathrm{rpm}$ for 15 min ensued, and the pellet was washed with ethanol $70 \%$. The plasmid DNA therefrom extracted was resuspended in $50 \mathrm{~mL}$ TE supplemented with $3 \mathrm{~mL}$ Rnase (to a final concentration of $0.3 \mathrm{mg} / \mathrm{mL}$ ), kept for $1 \mathrm{~h}$ at room temperature and then stored at $-20^{\circ} \mathrm{C}$.

\section{Primers}

The primers (CyberSyn Biodynamics, USA) used in the detection of enterotoxigenic E. coli were designed based on the complete sequences of the target genes of reference $[8,20]$. The pair of primers LT10 and LT11 is complementary to the gene encoding the heat-labile enterotoxin and amplifies a 221bp fragment.

LT10 5'-CGATGGCAGGCAAAAGAGAA-3'; LT115'-GTTTTCCATACTGATTGCCG-3'
The pair of primers ST10 and ST11 is complementary to the gene encoding the heat-stable enterotoxin and amplifies a 167-bp fragment.

\section{ST10 5'-GTCTTTTTCACCTTTCGCTC-3'; ST11 5' -TACAAGCAGGATTACAACAC -3'}

\section{The PCR assay}

Reactions were carried out in a final volume of $25 \mathrm{~mL}$ containing the following compounds: reaction buffer $1 \mathrm{X}(200 \mathrm{mM}$ Tris- $\mathrm{HCl}, 500 \mathrm{~mL} \mathrm{KCl})$, $2,5 \mathrm{mM}$ of each deoxynucleotide, $200 \mathrm{ng}$ bovine serum albumin (BSA), $30 \mathrm{ng}$ of each primer, 0.5 U Taq DNA, and $30 \mathrm{ng}$ template DNA. The reactions took place under the following conditions:

ST10 and ST11: one initial cycle $\left(1 \mathrm{~min}, 95^{\circ} \mathrm{C} ; 5 \mathrm{~min}\right.$ at $61^{\circ} \mathrm{C} ; 2 \mathrm{~min}$ at $\left.72^{\circ} \mathrm{C}\right)$, and 35 cycles $\left(45 \mathrm{~s}\right.$ at $95^{\circ} \mathrm{C}$; $45 \mathrm{~s}$ at $48^{\circ} \mathrm{C} ; 90 \mathrm{~s}$ at $72^{\circ} \mathrm{C}$ ).

LT10 and LT11: one initial cycle $\left(1 \mathrm{~min}, 95^{\circ} \mathrm{C} ; 5 \mathrm{~min}\right.$ at $61.5^{\circ} \mathrm{C} ; 2$ min at $\left.72^{\circ} \mathrm{C}\right)$, and 35 cycles $\left(30 \mathrm{~s}\right.$ at $95^{\circ} \mathrm{C}$; $30 \mathrm{~s}$ at $61.5^{\circ} \mathrm{C} ; 60 \mathrm{~s}$ at $72^{\circ} \mathrm{C}$ ).

\section{Agarose gel electrophoresis}

The amplified product was visualized in 1,2\% agarose gel, in a transluminator under UV light. Gels were photographed and digitally stored using the Kodak software, version 35.2.

\section{Statistical analysis}

The microbial diversity as established for each sampling site and between the different sampling sites was assessed using the ANOVA variance analysis.

\section{RESULTS}

\section{Bacterial characterization}

For the three sample collections carried out in the slaughterhouse and processing unit, 580 bacteria were isolated and identified, grouped under 9 genera and 18 species. The specie occurring most frequently was Staphylococcus aureus, followed by Escherichia coli (Table 1). Staphylococcus aureus was detected at high counts in all sampling sites, as of all three sample collections (Tables 2, 3, and 4) and also in the environment (Table 5).

The comparative bacterial diversity for the four sampling sites inspected along the three collections was not statistically significant $(p<0.05)$, according to the ANOVA results. Throughout the experiment, es- 
sentially the same species were isolated and identified in site 1 (boning desk).

At site 2 (mixer), no significant bacterial diversity was found throughout the experiment, though at the second and third collections the prevalence of S. aureus was seen (Tables 3 and 4). Regarding the second collection, no E. coli was identified in samples from this sampling site.

Considering the distribution of Corynebacterium vitarumem, it was at first identified in site 2 , and proceeded to be isolated in samples from the other sites in the other collections (Tables 2, 3 and 4).

Bacterial diversity was modest in site 3 (skinencased desk). As of the first and third collection at that site, E. coli counts were significant and prevailing (Tables 2 and 4). The second collection, in turn, shown a prevalence of $S$. aureus followed by the Enterobacteriaceae family.

Site 4 (sealing machine) revealed a considerable E. coli count at the first sample collection, but the prevalent species was Corynebacterium vitarumem (Table 2).

The second sample collection showed the prevalence of Staphylococcus aureus isolates, with the Enterobacteriaceae family coming next. It is to be noticed that as of the second collection, a greater bacterial diversity - though not statistically significant $(p<0.05)$ - was observed, when compared to the other collections. No such evident prevalence of one given microorganism was seen at the third collection; nevertheless, Escherichia coli, Staphylococcus aureus and the Enterobacteriaceae family still occurred more frequently than the other species (Table 4).

\section{Coliforms}

The highest figures for faecal coliforms were observed at sampling sites 1 and 3, boning desk and sealing machine respectively, with and average of $1.7 \times 10^{3}$ and $8.7 \times 10^{3}$ per sampling area. There has been a decay in faecal and total coliforms in the second sample collection and again the numbers raised at the third collection (data not shown). $(\mathrm{n}=182)$.

Table 1. Overall distribution of bacterial species isolated and characterized via classic biochemical assays.

\begin{tabular}{lc}
\hline \multicolumn{1}{c}{ Bacteria species } & Number of isolates \\
\hline Staphylococcus aureus & 168 \\
Escherichia coli & 123 \\
Corynebacterium vitarumem & 79 \\
Enterobacter agglomerans & 40 \\
Serratia marcescens & 37 \\
Klebsiella pneumoniae & 31 \\
Enterobacter cloacae & 29 \\
Bacillus subtilis & 17 \\
Corynebacterium sp. & 11 \\
Enterobacter hafniae & 9 \\
Citrobacter freundii & 8 \\
Enterobacter aminigenus & 7 \\
Bacillus coagulans & 5 \\
Bacillus stearothermophilus & 4 \\
Proteus mirabilis & 4 \\
Corynebacterium sp. & 3 \\
Proteus penneri & 2 \\
Corynebacterium paurometabolum & 4 \\
Bacillus cereus & 3 \\
\hline TOTAL & 3 \\
\hline & \\
\hline
\end{tabular}

Table 2. Bacterial species characterized at sampling sites, first sample collection

\begin{tabular}{lcccc}
\hline \multicolumn{1}{c}{ Bacteria species } & Site 1 & Site 2 & Site 3 & Site 4 \\
\hline Bacillus coagulans & 0 & 0 & 1 & 0 \\
Bacillus subtilis & 5 & 0 & 0 & 0 \\
Citrobacter freundii & 4 & 0 & 0 & 2 \\
Corynebacterium sp. & 0 & 0 & 0 & 1 \\
Corynebacterium paurometabolum & 0 & 0 & 0 & 2 \\
Corynebacterium vitarumem & 0 & 16 & 15 & 18 \\
Enterobacter agglomerans & 0 & 6 & 2 & 0 \\
Enterobacter aminigenus & 0 & 0 & 0 & 7 \\
Escherichia coli & 15 & 13 & 13 & 16 \\
Klebsiella pneumoniae & 0 & 0 & 5 & 0 \\
Proteus penneri & 1 & 0 & 0 & 0 \\
Staphylococcus aureus & 17 & 10 & 9 & 4 \\
\hline TOTAL & 42 & 45 & 45 & 50 \\
\hline
\end{tabular}




\section{Characterization of enterotoxigenic Escherichia coli via PCR}

The 123 bacteria characterized in the classic biochemical assays as being Escherichia coli underwent the PCR protocol to establish the presence of LT and ST genes. Thirty-seven isolates out of that number were positive for ST gene. In the ST-positive group, 20 bacteria were at the same time LT-positive and 2 isolates were characterized as solely LT-positive. In this study, out of the 39 samples positive for ETEC, 14 were isolated from the mixer samples.

\section{DISCUSSION}

Staphylococcus aureus was the most common microorganism detected in all sample collections. According to some studies, $S$. aureus is found as a matter of course in the hides of cattle, and in this way spreads over the slaughterhouse and chilling/processing facility [5,19].

Analyzing the results as a whole, the presence of a great number of Escherichia coli may be imputed to the contamination of carcasses with faecal matter as of evis$(n=162)$.
Table 3. Bacterial species characterized at sampling sites, second sample collection

\begin{tabular}{lcccc}
\hline \multicolumn{1}{c}{ Bacteria species } & Site 1 & Site 2 & Site 3 & Site 4 \\
\hline Bacillus coagulans & 2 & 0 & 0 & 0 \\
Bacillus stearothermophilus & 0 & 4 & 0 & 0 \\
Bacillus subtilis & 6 & 0 & 0 & 0 \\
Citrobacter freundii & 2 & 0 & 0 & 0 \\
Corynebacterium sp. & 0 & 2 & 0 & 0 \\
Corynebacterium pseudodiphtheriticum & 0 & 0 & 0 & 3 \\
Corynebacterium vitarumem & 0 & 4 & 5 & 0 \\
Enterobacter agglomerans & 2 & 5 & 7 & 4 \\
Enterobacter cloacae & 4 & 0 & 1 & 8 \\
Enterobacter hafniae & 0 & 0 & 9 & 0 \\
Escherichia coli & 4 & 0 & 4 & 6 \\
Klebsiella pneumoniae & 11 & 0 & 1 & 1 \\
Serratia marcescens & 0 & 5 & 3 & 2 \\
Staphylococcus aureus & 9 & 20 & 11 & 17 \\
\hline TOTAL & 40 & 40 & 41 & 41 \\
\hline
\end{tabular}

Table 4. Bacterial species characterized at sampling sites, third sample collection $(n=176)$.

\begin{tabular}{lcccc}
\hline \multicolumn{1}{c}{ Bacteria species } & Site 1 & Site 2 & Site 3 & Site 4 \\
\hline Bacillus coagulans & 2 & 0 & 0 & 0 \\
Bacillus subtilis & 5 & 0 & 0 & 0 \\
Corynebacterium sp. & 0 & 2 & 5 & 1 \\
Corynebacterium vitarumem & 0 & 5 & 6 & 4 \\
Enterobacter agglomerans & 1 & 1 & 0 & 7 \\
Enterobacter cloacae & 7 & 0 & 4 & 1 \\
Escherichia coli & 5 & 4 & 18 & 10 \\
Klebsiella pneumoniae & 1 & 3 & 4 & 2 \\
Proteus mirabilis & 0 & 0 & 4 & 0 \\
Serratia marcescens & 12 & 7 & 0 & 8 \\
Staphylococcus aureus & 11 & 23 & 4 & 9 \\
\hline TOTAL & 44 & 45 & 45 & 42 \\
\hline
\end{tabular}

in literature. Only one isolation of that genus in bovine slaughterhouses and processing/chilling units was found. In a study on the biota commonly found in bovine hides it was observed that Corynebacterium and Bacillus genus and the species Staphylococcus aureus make up that bacterial population, with the Staphylococcus genus being responsible for $70 \%$ of that biota [19]. Thus, the constant detection of Corynebacterium in this study may be imputed to the spreading of the microorganism from hides into the environment during slaughter.

The presence of coliform bacteria is often used as an indica- 
tor of the overall sanitary quality of food, soil and water environments. Use of an indicator such as coliforms, as opposed to the actual disease causing organisms, is advantageous as the indicator usually occur at higher frequencies than the pathogens and are simpler and safer to detect

According to the Brazilian National Agency For Sanitary Inspection [13], in a resolution published on 2 January 2001, the faecal coliform count in chilled or frozen beef in natura must not exceed $10^{4}$ coliforms/gram. Should this figure be used in the microbiological control of the environment, all sampling sites in this study would lie within the aforementioned limit. Yet, the desk where skin-encased products are filled (site 3) showed a faecal count that may well be considered as bordering that upper limit when the third sample collection is considered .

As regards the gene pattern of ETEC, this study revealed the existence of a higher number of $\mathrm{ST}^{+}$ isolates compared with the number of positive for both ST and LT genes. In studies on enterotoxigenic Escherichia coli isolated from pigs, the authors concluded that the prevailing gene pattern for animals having diarrhea is the presence of the ST gene [14].

Studies on ETEC demonstrated that strains expressing the ST alone or jointly with the LT gene are associated to diarrhea; nevertheless, there is no evidence proving Escherichia coli expressing the LT gene alone as able to start an outbreak of diarrhea. The prevalence of the ST/LT or ST alone gene patterns has been proved for ETEC-diagnosed diarrhea cases [21].

A work done with ETEC revealed that approximately one third of the ETEC strains related to disea-

\begin{tabular}{lccc}
\multicolumn{4}{c}{ Table 5. Bacterial species characterized at the environment $(\mathrm{n}=60)$} \\
\hline \multicolumn{1}{c}{ Bacteria species } & $\begin{array}{c}\mathbf{1}^{\text {st }} \text { sample } \\
\text { collection }\end{array}$ & $\begin{array}{c}\mathbf{2}^{\text {nd }} \text { sample } \\
\text { collection }\end{array}$ & $\begin{array}{c}\mathbf{3}^{\text {rd }} \text { sample } \\
\text { collection }\end{array}$ \\
\hline Bacillus cereus & 1 & 0 & 0 \\
Bacillus subtilis & 0 & 1 & 0 \\
Corynebacterium vitarumem & 1 & 4 & 1 \\
Enterobacter agglomerans & 0 & 2 & 3 \\
Enterobacter cloacae & 0 & 0 & 4 \\
Escherichia coli & 6 & 8 & 4 \\
Klebsiella pneumoniae & 0 & 3 & 0 \\
Proteus penneri & 1 & 0 & 0 \\
Staphylococcus aureus & 11 & 2 & 20 \\
\hline TOTAL & 20 & 20 & 32 \\
\hline
\end{tabular}

ses expressed both LT and ST genes, whereas two thirds expressed one of the two genes at a time [17]. In a study on the phenotypical diversity of diarrhea-associated ETEC, 100 ETEC isolates were obtained, out of which 57 were $\mathrm{ST}^{+} \mathrm{LT}^{-}$and only 9 were positive for both genes [15]. In a work designed to detect virulence factors in Escherichia coli isolated from pig faeces the LT gene was detected at low range [18].

In this study, most of the ETC samples were isolated from the mixer samples. That equipment does not keep direct contact with the environment and thus, as should be expected, contamination would be lower. The bacterial contamination via faeces is not seen as necessarily circumscribed to areas of visible faecal contamination according to some authors [10]. This leads us to postulate that in equipment, competition and the bacterial counts would be lower, and so promote the development of those microorganisms.

The presence of ETEC is linked to inadequate hygienic and sanitary procedures [6] and, particularly in our study, the presence of ETEC in all sampling sites before processes in slaughterhouse and processing/ chilling unit makes clear that only the end-of-shift cleaning is not sufficient to either eradicate pathogenic microorganisms or to inhibit cross-contamination seen in the plant.

The slaughterhouse plant and the meat processing/chilling steps play important roles in microorganism dissemination in animal carcasses after slaughter, and the presence of pathogenic bacteria such as ETEC in such animal products poses considerable health hazards for the consumers of meat products.

Our results indicated that microorganism contamination in the slaughterhouse plant under investigation in this study was detected from the arrival of animals, disseminating to the beef processing endpoint. Such findings demonstrate the potential risk for the consumers' health, emphasizing the importance of the implementation of appropriate sanitary procedures and measures for the contention of carcass and environment contamination at slaughterhouses.

In this regard, the knowledge of critical contamination spots in- 
side a slaughterhouse/processing unit is essential for the prevention and resolution of contamination problems by the use of appropriate sanitary measures and strategic control $[3,4]$.

The characterization of ETEC was important to identify sources of such contamination and to define whether sanitary procedures adopted in the slaughterhouse and processing unit were effective in eliminating those bacteria. The results obtained in this study revealed that basic hygiene and disinfection routines lack the required sanitary effectiveness, since the environmental assessment prior to slaughter showed bacterial contamination, indicating that alternative cleaning procedures using sanitizers are required before the beginning of the slaughter on a daily basis.

\section{REFERENCES}

1 APHA. 1998. Standard methods for examination of water and wastewater. 20th edn. New York: American Public Health Association, 1190p.

2 Bonardi S., Maggi E., Pizzin G., Morabito S. \& Caprioli A. 2001. Faecal carriage verocytotoxin-producing Escherichia coli $\mathrm{O} 157$ and carcass contamination in cattle at slaughter in northern Italy. International Journal of Food Microbiology. 66: $47-53$.

3 Bouvet J., Montet M.P., Rossel R., Le RouxA., Bavai C.L., Ray-Gueniot S., Mazuy C., Atrache V. \& Vernozy-Rozand C. 2002. Effects of slaughter processes on pig carcass contamination by verotoxin-producing Escherichia coli and E. coli 0157:H7. International Journal of Food Microbiology. 77: 99-108.

4 Cerqueira M.F.A., Guth B.E.C., Joaquim R.M. \& Andrade J.R.C. 1999. High ocurrence of Shiga toxin-producing Escherichia coli (STEC) in healthy cattle in Rio de Janeiro State, Brazil. Veterinary Microbiology. 70: 111-121.

5 Chen T.R., Hsiao M.H., Chiou C.S. \& Tsen H.Y. 2001. Development and use of PCR primers for the investigation of C1, $\mathrm{C} 2$ and C3 enterotoxin types of Staphylococcus aureus strains isolated from food-borne outbreaks. International Journal of Food Microbiology. 71: 63-70.

6 Clarke S.C. 2001. Diarrhoeagenic Escherichia coli - an emerging problem? Diagnostic Microbiology and Infectious Disease. 41: 93-98.

7 Deng M.Y., Cliver D.O., Day S.P. \& Fratamico P.M. 1996. Enterotoxigenic Escherichia coli detected in foods by PCR and an enzyme-linked oligonucleotide probe. International Journal of Food Microbiology. 30: 217-229.

8 Dwarakanath P., Visweswariah S.S., Subrahmanyam Y.V.B.K., Shanthi G., Jagannatha H.M. \& Balganesh T.S. 1989. Cloning and hyperexpression of a gene encoding the heat-stable toxin of Escherichia coli. Gene: 81: 219-226.

9 Gun H., Yilmaz A., Turker S., Tanlasi A. \& Yilmaz H. 2003. Contamination of bovine carcasses and abattoir environment by Escherichia coli O157:H7 in Istanbul. International Journal of Food Microbiology. 84: 339-344.

10 Heuvelink A.E., Roessink G.L., Bosboom K. \& Boer E. 2001. Zero-tolerance for faecal contamination of carcasses as a tool in the control of O157 VTEC infections. International Journal of Food Microbiology. 66: 13-20.

11 Holt J.G., Krieg N.R., Sneath P.H.A., Staley J.T. \& Stanley T.W. 1994. Bergey's Manual of Determinative Bacteriology. Baltimore: Willians \& Wilkins, 787p.

12 MacFaddin J.F. 2000. Biochemical test for identification of medical bacteria. Baltimore: The Williams \& Wilkins. 1312p.

13 Ministério da Agricultura e do Abastecimento. 1997. Regulamento de Inspeção Industrial e Sanitária de Produtos de Origem Animal. Brasília: Ministério da Agricultura e do Abastecimento, pp.1-53.

14 Parma A.E., Sanz M.E., Vinãs M.R., Cicuta M.E., Blanco J.E., Boehringer S.I., Vena M.M., Roibon W.R., Benitez M.C., Blanco J. \& Blanco M. 2000. Toxigenic Escherichia coli isolated from pigs in Argentina. Veterinary Microbiology. 72: 269-276.

15 Peruski L.F., Bradford A.K., El-Yazeed R.A., El-Etr S.H., Cravioto A., Wierzba T.F., Rao M., El-Ghorab N., Shaheen H., Khalil S.B., Kamal K., Wasfy M.O., Svennerholm A.M., Clements J.D. \& Savarino S. 1999. Phenotypic diversity of enterotoxigenic Escherichia coli strains from a community-based study of pediatric diarrhea in Periurban Egypt. Journal of Clinical Micriobiology. 37: 2974-2978.

16 Sambrook J., Fritsch E.F. \& Maniats T. 1989. Molecular Cloning A Laboratory Manual. New York: Cold Spring Harbor laboratory, 1355p.

17 Schlör S., Riedl S., Blab J. \& Reidl J. 2000. Genetic rearrangements of the regions adjacent to genes encoding heat-labile enterotoxins (elt $\mathrm{AB}$ ) of enterotoxigenic Escherichia coli strains. Applied and Environmental Microbiology. 66: 352-358. 
18 Silva A.S., Valadares G.F., Panetti M.P.A., Brito B.G. \& Leite D.S. 2001. Escherichia coli strains from edema disease: O serogroups, and genes for Shiga toxin enterotoxins, and F18 frimbriae. Veterinary Microbiology. 80: $227-233$.

19 Woodward W.D., Ward A.C.S., Fox L. \& Corbeil L.B. 1988. Test skin normal flora and colonization with mastitis pathogen inhibitors. Veterinary Microbiology. 17: 357-365.

20 Yamamoto T. \& Yokota T. 1983. Sequence of heat-labile enterotoxin of Escherichia coli pathogenic for humans. Journal of Bacteriology. 155: 728-733.

21 Yavzori M., Porath N., Ochana O., Dagan R., Wasserlauf R.O. \& Cohen D. 1998. Detection of enterotoxigenic Escherichia coli in stool specimens by polymerase chain reaction. Bacteriology. 31: 503-598. 